\title{
SUBJECTIVE WELL-BEING PADA REMAJA DARI KELUARGA BROKEN HOME
}

\author{
Yuli Astuti* dan Nisa Rachmah Nur Anganthi** \\ *Jl. Pracimantoro-Wonogiri, Sindukarto, Eromoko, \\ Kabupaten Wonogiri, Jawa Tengah, Indonesia \\ **Magister Psikologi Universitas Muhammadiyah Surakarta \\ Jl. A. Yani, Tromol Pos 1 Pabelan, Surakarta \\ Email: Nisa.Rachmah.Nur.Anganthi@ums.ac.id
}

\begin{abstract}
This research aims to describe the factors influencing teenagers' subjective wellbeing and the subjective well-being condition in broken home teenagers. This is a quantitative research with a phenomenology approach. The subjects are three junior high school students in the district of Wonogiri who has the following characteristics: (1) teenagers from broken home families and (2) 12 - 16 years old of ages. The data gathering methods include interview and observations. The data analyses procedures covers open coding, axical coding and selective coding. The results show that the factors influencing subjective well-being in teenagers includes social support, parental guidance, gender, finance, and coping strategy. The subjective well-being in Vn ad DN are better than informan An. It occurs in life satisfaction asspect and apparently showed in some facts, such as graduating elementary school with good grades and getting a bicycle as a present. Some acts that can bring positive effect covers vacation with the family, helping the family, sports championships and getting good grades at school. The acts that can bring negative effect include feeling guilty, do not have pocket money, negative thoughts toward father and the neighbours, thinking off father, getting bad grades, family loss, mother who always gets angry, and jealousy towards friends.
\end{abstract}

Keywords: subjective well-being; broken home, teenagers, qualitative research

\begin{abstract}
ABSTRAK
Tujuan penelitian ini adalah mendeskripsikan faktor-faktor yang mempengaruhi subjective well-being pada remaja, dan kondisi subjective well-being pada remaja yang mengalami broken home. Penelitian ini merupakan penelitian kualitatif dengan pendekatan fenomenologis. Subjek penelitian yaitu 3 siswa SMP, Kabupaten Wonogiri yang memiliki karakteristik (1) anak berasal dari keluarga broken home dan (2) berusia 12 tahun sampai dengan 16 tahun. Metode pengumpulan data menggunakan wawancara dan observasi. Prosedur analisis data dengan tahap Open Coding (koding terbuka), Axial Coding (koding aksial), Selective Coding (koding selektif). Hasil penelitian menunjukkan faktor-faktor yang mempengaruhi subjective well-being, yaitu dukungan sosial, pola asuh orang tua, jenis kelamin, ekonomi, strategi coping. Subjective well-being pada informan Vn dan DN lebih baik daripada informan An. Subjective well-being pada aspek life satisfaction, muncul dalam beberapa peristiwa, seperti: lulus SD dengan nilai baik, mendapat hadiah sepeda. Peristiwa yang memunculkan positive affect antara lain: berlibur bersama keluarga, membantu keluarga, juara perlombaan olah raga, mendapatkan nilai baik. Peristiwa yang memunculkan negatif affect diantaranya; merasa bersalah dan menjadi beban, tidak
\end{abstract}


mempunyai uang saku sekolah, prasangka negatif terhadap ayah dan tetangga, sedih jika memikirkan ayah, mendapatkan nilai jelek, kakek-nenek dari ayah meninggal, selalu dimarahi ibu, dan iri pada teman-teman.

Kata Kunci: subjective well-being; broken home, remaja, penelitian kualitatif.

\section{PENDAHULUAN}

Kebahagiaan di dalam hidup adalah suatu hal yang menjadi harapan di dalam kehidupan banyak orang, bahkan sepertinya semua orang mendambakan kehidupan yang berbahagia. Menurut Seligman (2006) istilah kebahagiaan mulai dikenal dalam psikologi positif. Teori psikologi menggunakan istilah yang lebih tepat yang dapat didefinisikan secara operasional, yakni subjective well-being yang selanjutnya akan disebut dengan SWB, bukan kebahagiaan.

Hingga saat ini masih terdapat perbedaan pendapat mengenai sumber dan penyebab kebahagiaan. Sejumlah pakar mengidentikkan kebahagiaan dengan waktu dan pengalaman hidup yang menyenangkan. Penelitian Thomas dan Diener (Diener, dkk., 2005) menemukan bahwa kebahagiaan dipengaruhi oleh suasana hati individu pada suatu saat tertentu, keyakinannya tentang kebahagiaan, serta seberapa mudahnya seseorang menerima informasi positif dan negatif. Di sisi lain, kebahagiaan juga berkaitan dengan seberapa mampu individu mempersepsi pengalaman hidupnya secara positif. Tingkat kebahagiaan akan berubah seiring berjalannya perjalanan hidup seseorang, terutama karena kejadian-kejadian hidup yang dapat meningkatkan kebahagiaan (pernikahan, kelahiran anak, kesuksesan, dll.). Namun kebahagiaan juga dapat menurun karena adanya peristiwa yang menyedihkan (kematian kerabat, perceraian, dan kegagalan) sehingga tingkat kebahagiaan tidak akan menetap. Perubahan tingkat kebahagiaan seseorang disebabkan oleh kemampuan adaptasi individu terhadap situasi di lingkungannya.

Seseorang akan lebih berbahagia ketika mendapatkan pengalaman yang menyenangkan. Begitu juga sebaliknya, ketika seseorang kecewa dengan pengalamannya, seperti liburan yang ternyata mengecewakan, ataupun usaha yang kemudian gagal, hal ini akan membuat kebahagiaan menurun. King (dalam Wirawan, 2010) mengemukakan pengalaman yang buruk akan lebih cepat menurunkan tingkat kebahagiaan dibandingkan dengan kegagalan dalam memilih barang yang bersifat hanya material. Namun demikian, kemampuan seseorang untuk melakukan introspeksi dan mengambil hikmah dari berbagai peristiwa yang terjadi ternyata berperanan juga terhadap kebahagiaannya. Laura King, peneliti dari University of Missouri, mengindikasikan bahwa individu yang menghabiskan waktu untuk memikirkan kesalahan yang telah mereka lakukan (instropeksi diri) cenderung menjadi lebih dewasa dan dapat menambah potensi kebahagiaan mereka. King menemukan bahwa orang-orang yang dapat menunjukkan perkembangan kepribadian adalah orang-orang yang pernah merasakan kehilangan.

Mengingat pentingnya kebahagiaan bagi individu, maka timbul pertanyaan mengenai faktor-faktor apa saja yang mempengaruhi remaja memiliki subjective well-being dan bagaimana kondisi subjective well-being pada remaja broken home? Menurut Kartono (2010) keluarga memegang peranan yang sentral dalam perkembangan sosial anak-anak, hal ini tidak perlu diragukan lagi karena keluarga merupakan kelompok yang pertama dalam kehidupan manusia. Keluarga merupakan tempat anak-anak belajar dan menyatakan diri sebagai manusia sosial dalam hubungan interaksi dengan kelompoknya.

Salah satu masalah dalam kehidupan yang dianggap paling berat adalah masalah yang terjadi dalam keluarga. Keluarga inti (nuclear family) adalah suatu wadah dimana anak berkembang dan bertumbuh, baik secara fisik maupun psikologis. Dalam kebanyakan kasus 
broken home anak selalu menjadi atau dijadikan korban. Menjadi korban karena haknya mendapat lingkungan keluarga yang nyaman telah dilanggar. Dijadikan korban karena orang tua kerap melibatkan anak dalam konflik keluarga. Kondisi ini menimbulkan dampak yang sangat besar bagi remaja yang dalam proses perkembangannya merupakan saat-saat pembentukan karakter dan kepribadian, terutama untuk kehidupannya di masa yang akan datang.

Ketidakhadiran orang tua atau ditinggalkan dari salah seorang orang tuanya dapat menimbulkan emosi, dendam, sedih, marah, dan benci sehingga dapat mengakibatkan perkembangan anak terganggu. Sebagaimana Kartono (2010) mengatakan sebagai akibat dalam keluarga yang kurang harmonis, anak tidak mendapat kebutuhan fisik ataupun psikis, anak menjadi risau, sedih, sering diliputi perasaan dendam, benci, sehingga anak menjadi kacau dan nakal. Maramis (2000) mebambahkan akibat sikap orang tua yang kurang memperhatikan anak; bahwa anak yang bersangkutan merasa ditolak dan tidak dicintai; mereka mempunyai hasrat untuk membalas dendam disertai dengan perasaan yang tidak bahagia dan agresif karena dengan kelakuan yang baik ia tidak mendapatkan perhatian dan kasih sayang; maka ia mencari jalan lain untuk mendapatkan perhatian di luar rumah yaitu cara yang negatif dan dapat menggangu orang lain. Anak merasa tidak bahagia dan dipenuhi konflik batin akhirnya anak mengalami frustrasi, menjadi agresif, dan nakal.

Anak yang hidup di lingkungan keluarga broken home berpotensi mengalami banyak permasalahan dalam perkembangan kehidupannya. Mulai dari masalah pergaulan, masalah akademik, maupun masalah perkembangan kepribadian, misalnya menjadi anak pemurung, menarik diri dalam pergaulan, rendah diri, merasa sulit untuk beradaptasi dengan temantemannya, lebih senang menyendiri serta mudah marah atau sensitif. Pertanyaan selanjutnya yang muncul berkenaan dengan latar belakang permasalahan di atas adalah faktor-faktor apa yang mempengaruhi pembentukan subjective well-being pada remaja dari keluarga broken home?

\section{METODE PENELITIAN}

Pendekatan yang digunakan dalam penelitian ini adalah pendekatan kualitatif fenomenologis. Fokus penelitian ini adalah subjective well-being pada remaja dari keluarga broken home. Subjective well-being didefinisikan sebagai ukuran kebahagiaan yang dirasakan oleh seseorang dengan cara melakukan evaluasi terhadap kehidupannya. Evaluasi ini meliputi evaluasi kognitif dan evaluasi afektif. Adapun broken home adalah kondisi keluarga yang tidak harmonis dan tidak berjalan dengan rukun, damai, dan sejahtera karena sering terjadi keributan serta perselisihan yang menyebabkan pertengkaran hingga diakhiri dengan perceraian.

Pemilihan informan dalam penelitian ini memakai pendekatan purposive, yaitu informan penelitian dipilih menurut criteria tertentu. Kriteria pemilihan informan dalam penelitian ini adalah (1) anak berasal dari keluarga yang tidak harmonis (broken home) dan (2) Berusia 12 tahun sampai dengan 16 tahun. Penelitian ini mengambil lokasi di sebuah SMP Kabupaten Wonogiri karena dalam data sekolah cukup banyak siswa yang kondisi keluarganya broken home.

Peneliti menggunakan metode wawancara mendalam (in-depth interview) dan metode dokumentasi. Analisis data dilakukan dengan memberikan koding terhadap data-data yang telah diperoleh. Adapun langkah-langkah dalam koding adalah: (1) menyusun transkripsi verbatim atau catatan lapangan, (2) secara urut dan kontinyu melakukan penomoran pada baris-baris transkrip dan /atau catatan lapangan, (3) memberikan nama untuk masing-masing berkas dengan kode tertentu, serta (4) membubuhkan tanggal pada tiap-tiap berkas. 


\section{HASIL DAN PEMBAHASAN}

Berdasarkan hasil pengkategorian aspek-aspek SWB diketahui informan VN cenderung memiliki kepuasan ketika lulus SD dengan nilai yang baik. VN juga merasa bahagia karena mendapatkan kasih sayang dari Pakde-Bude dan merasa sudah mendapat pengganti orang tua kandung yang dapat memberikan kasih sayang sepenuhnya serta informan dapat bergaul di lingkungan sosial dengan baik. Pada aspek positive affect diketahui informan selalu bersemangat menjalani hidup meskipun banyak persoalan yang dialami, informan memahami perceraian yang sudah terjadi merupakan takdir yang harus terjadi karena kehendak Tuhan. Informan juga mampu mengalihkan berbagai masalah dengan aktivitas yang positif, yaitu dengan membantu Pakde-Bude membersihkan rumah. Pada negative affect informan kecewa dan sedih karena kesulitan keuangan dan Pakde-Bude sering bertengkar masalah ekonomi.

Tabel 1

Kategorisasi SWB pada Informan Vn

\begin{tabular}{lll}
\hline Kategori & Peristiwa & Interpretasi \\
\hline
\end{tabular}

A. Kepuasan Hidup:

1. Bangga Lulus SD dengan nilai bagus

2. Bahagia

3. Senang

B. Afek Positif:

1. Semangat

2. Berpikir positif

3. Senang \& Bahagia

4. Rajin

C. Afek Negatif:

1. Kecewa

2. Sedih
Diberi motivasi oleh Pakde-Bude agar tetap semangat

Menyadari perceraian orang tua adalah takdir yang memang harus di jalani

Diajak berlibur ke rumah ayah, ketika keluarga masih utuh membantu bersih-bersih rumah , Ingin mengalihkan masalah dengan aktivitas positif di rumah

-Komunikasi dengan orang tua terputus

- Tidak tahu tempat tinggal orang tua

-kesulitan keuangan

- Pakde-Bude bertengkar masalah ekonomi

-bapak tidak pernah kasih uang
Keberhasilan yang dicapai di sekolah salah satu keberhasilan terbesar yang diraih

Mendapat pengganti orang tua kandung yang dapat memberikan kasih sayang

Informan dapat bergaul di lingkungan sosial dengan baik

Informan berusaha bersemangat menjalani hidup

Informan memahami kejadiankarena kehendak tuhan, memahami nilai-nilai religiusitas

Rekreasi bersama keluarga, dapat menciptakan rasa bahagia Informan dapat memilih coping yang positif

Seperti merasa ditelantarkan orang tua kandung

Informan khawatir tidak bisa melanjutkan sekolah Informan merasa menjadi beban ekonomi tambah berat

Berdasarkan hasil pengkategorian aspek-aspek SWB diketahui informan VN merasakan kepuasan ketika lulus SD dengan nilai yang baik. VN juga merasa bahagia karena mendapatkan kasih sayang dari Pakde-Bude dan merasa sudah mendapat pengganti orang tua kandung 
yang dapat memberikan kasih sayang sepenuhnya, dan informan dapat bergaul di lingkungan sosial dengan baik. Pada aspek afek positif diketahui informan selalu bersemangat menjalani hidup meskipun banyak persoalan yang dialami, informan memahami perceraian yang sudah terjadi merupakan takdir yang harus terjadi karena kehendak tuhan. Informan juga mampu mengalihkan berbagai masalah dengan aktivitas yang positif, yaitu dengan membantu PakdeBude membersihkan rumah. Pada afek negatif informan kecewa dan sedih karena kesulitan keuangan dan Pakde-Bude sering bertengkar masalah ekonomi.

Tabel 2

Kategorisasi SWB pada Informan Dn

\begin{tabular}{|c|c|c|}
\hline Kategori & Peristiwa & Interpretasi \\
\hline \multicolumn{3}{|l|}{ A. Kepuasan Hidup: } \\
\hline 1. Merasa Nyaman, damai & $\begin{array}{l}\text { Tinggal bersama ibu membuat perasaan } \\
\text { tenang dan nyaman }\end{array}$ & $\begin{array}{l}\text { Memiliki kelekatan yang kuat } \\
\text { dengan ibu }\end{array}$ \\
\hline 2. Bahagia & $\begin{array}{l}\text { Kedua orang tua tetap memberi } \\
\text { perhatian dan kasih saying }\end{array}$ & $\begin{array}{l}\text { Komunikasi dengan orang tua- } \\
\text { masih berjalan dengan baik }\end{array}$ \\
\hline 3. Puas & $\begin{array}{l}\text {-Ketika lulus SD, mendapat hadiah } \\
\text { sepeda } \\
\text {-Sudah menempati rumah sendiri } \\
\text { bersama ibu }\end{array}$ & $\begin{array}{l}\text { Informan merasakan kepuasan } \\
\text { dalam hidupnya karena berhasil } \\
\text { lulus dari SD }\end{array}$ \\
\hline \multicolumn{3}{|l|}{ B. Afek Positif: } \\
\hline 1. Senang & $\begin{array}{l}\text {-Ayah sering menelpon } \\
\text {-diajak jalan-jalan kakek } \\
\text { - ibu sangat perhatian }\end{array}$ & $\begin{array}{l}\text { Mendapat dukungan sosial yang } \\
\text { tinggi dari orang tua dan kakek }\end{array}$ \\
\hline 2. Puas & -liburan ke ancol Jakarta & \\
\hline 3. Bersemangat & Ketika bertemu dengan teman-teman & dapat bergaul dengan teman-teman \\
\hline \multicolumn{3}{|l|}{ C. Afek Negatif: } \\
\hline 1. Kecewa & Kedua orang tua berpisah & $\begin{array}{l}\text { Tidak mengharapkan adanya } \\
\text { perceraian }\end{array}$ \\
\hline 2. Sedih & $\begin{array}{l}\text {-Ibu mencari nafkah sendiri } \\
\text {-memikirkan ayah }\end{array}$ & Sangat perhatian terhadap ibu \\
\hline 3. tidak bersemangat & $\begin{array}{l}\text {-ketika ibu sakit } \\
\text {-nilai sekolah jelek }\end{array}$ & \\
\hline
\end{tabular}

Berdasarkan hasil pengkategorian aspek SWB dapat diketahui informan merasakan kepuasan ketika lulus SD, dan tinggal di rumah sendiri bersama ibunya. Informan merasa hidup hidup damai dan teratur dengan ibu. Kondisi ini dapat dipengaruhi oleh adanya dukungan sosial dari orang-orang di sekitar informan. meskipun orang tua sudah berpisah informan masih mendapatkan perhatian dari ayah maupun ibunya, juga dari kakeknya. Orang-orang yang berperan di sekitar kehidupan informan adalah kakek, nenek dan ibu. Beberapa hal yang dapat membuat informan bersemangat adalah ketika mendapatkan nilai bagus, bertemu ayah dan teman-temannya. Hal yang tidak membuat semangat diantaranya nilai jelek, ibu sakit, dan memikirkan ayah. 
Tabel 3

Kategorisasi SWB pada Informan An

\begin{tabular}{|c|c|c|}
\hline Kategori & Peristiwa & Interpretasi \\
\hline \multicolumn{3}{|l|}{ A. Kepuasan Hidup: } \\
\hline 1.Bangga & -Juara 1 lompat jauh popda & $\begin{array}{l}\text { Meningkatkan keyakinan dan } \\
\text { optimis informan untuk mencapai } \\
\text { prestasi lebih tinggi }\end{array}$ \\
\hline 2. senang & $\begin{array}{l}\text { Mempunyai banyak teman dan } \\
\text { tetangga yang baik }\end{array}$ & $\begin{array}{l}\text { Dapat diterima dengan baik dalam } \\
\text { lingkungan sosial }\end{array}$ \\
\hline 3. Puas & Bertemu ayah kandung & $\begin{array}{l}\text { Informan berharap dapat sering } \\
\text { bertemu ayah kandung }\end{array}$ \\
\hline \multicolumn{3}{|l|}{ B. Afek Positif: } \\
\hline $\begin{array}{l}\text { 1. Optimis } \\
\text { 2. Bangga }\end{array}$ & -Juara 1 lompat jauh popda & $\begin{array}{l}\text { mempunyai keyakinan diri yang } \\
\text { tinggi untuk dapat menjadi atlet } \\
\text { nasional }\end{array}$ \\
\hline \multicolumn{3}{|l|}{ C. Afek Negatif: } \\
\hline $\begin{array}{l}\text { 1. Sedih } \\
\text { 2. Kecewa } \\
\text { 3. Marah } \\
\text { 4. Iri } \\
\text { 5. Tidak bersemangat }\end{array}$ & $\begin{array}{l}\text {-orang tua bercerai, } \\
\text {-ibu sering marah } \\
\text {-melihat ibu sering bertengkar dengan } \\
\text { ayah tiri } \\
\text { - kakek nenek bercerai } \\
\text {-iri dengan kehidupan orang lain yang } \\
\text { lebih baik Kesulitan keuangan }\end{array}$ & $\begin{array}{l}\text { Sering merasa hidup itu berat, } \\
\text { batinynya tertekan karena melihat } \\
\text { sikap ibu yang egois, berwatak } \\
\text { keras dan sering marah-marah }\end{array}$ \\
\hline
\end{tabular}

\section{Faktor yang mempengaruhi subjective well-being}

\section{a. Dukungan sosial}

Berdasarkan interpretasi terhadap data-data hasil penelitian diketahui bahwa faktor dukungan sosial cukup berpengaruh terhadap kondisi Subjective Well-Being pada informan. Semua informan mendapatkan dukungan sosial yang kuat terutama dari kakek dan neneknya, sedangkan informan $V n$ mendapat dukungan sosial dari Pakde dan Bude yang mengasuh dari kecil. Dukungan dapat mencakup aspek psikis maupun sosial, berkaitan dengan ulasan tersebut Wheatley (Taufik, 2010) mengungkapkan dukungan akan membangun kepercayaan dan kesadaran seseorang bahwa dia dipedulikan, dikasihi, dihargai, bernilai, dan merupakan bagian dari masyarakat yang saling mendukung dan membutuhkan. Ditambahkan oleh Champion dan Goodall (Taufik, 2010) dukungan dibutuhkan baik ketika individu sedang menderita stres maupun dalam kondisi normal, karena adanya dukungan sosial pada kondisi normal dapat menghalau atau dapat menjadi pertahanan kemungkinan terjadinya stres pada individu.

Menurut Hurlock (2008) ada beberapa gangguan psikologis yang timbul karenanya kurangnya dukungan sosial, diantaranya: (a) kesepian karena kebutuhan sosial tidak terpenuhi; (b) merasa tidak bahagia dan tidak aman; (c) potensial mengembangkan konsep diri yang negatif dan menimbulkan penyimpangan pribadi; (d) kurang memiliki pengalaman belajar yang dibutuhkan untuk menjalani proses sosialisasi; (e) merasa sangat sedih karena tidak memperoleh kegembiraan yang dimiliki teman sebaya mereka; dan (f) akan hidup dalam ketidakpastian tentang reaksi sosial, dan ini akan menyebabkan individu merasa cemas, takut dan sangat peka. 


\section{b. Pola asuh orang tua}

Peran orang tua juga sangat penting dalam pembentukan Subjective Well-Being. Pada ketiga informan ada peran orang tua yang sangat berbeda. Pada informan Vn perannya kedua orang tuanya (ayah dan ibu) sangat kecil. Orang tua Vn cenderung tidak peduli dengan keadaan informan . Bahkan Ibu sudah dua tahun tidak pulang, bapak tidak peduli dan tidak memberi kasih sayang semenjak Vn masih bayi sehingga yang lebih berperan sebagai pengganti orang tua, yaitu Pakde dan Bude-nya

Berbeda dengan informan Dn, informan mendapatkan perhatian yang cukup besar dari kedua orang tuanya. Ia tinggal bersama ibunya, yang meski bekerja tetapi masih sempat memperhatikan dan mengikuti perkembangan Dn, misalnya menanyakan keadaan sekolahnya dan menemani belajar. Ayah Dn juga masih memperhatikan dengan sering menelpon dan mengajak Dn menginap beberapa hari bersama ayahnya. Informan Dn cenderung memiliki kelekatan yang tinggi dengan ibunya. Kelekatan merupakan suatu ikatan emosional yang kuat yang dikembangkan anak melalui interaksinya dengan orang yang mempunyai arti khusus dalam kehidupannya, biasanya orang tua. Mc Cartney dan Dearing, (2002) menyatakan bahwa hubungan ini akan bertahan cukup lama dalam rentang kehidupan manusia yang diawali dengan kelekatan anak pada ibu atau figur lain pengganti ibu. Lebih lanjut Mc Cartney dan Dearing, (2002) mengemukakan pengetahuan anak didapatkannya dari interaksi dengan pengasuh, khususnya ibu. Anak yang memiliki orang tua yang mencintai dan dapat memenuhi kebutuhannya akan mengembangkan model hubungan yang positif yang didasarkan pada rasa percaya (trust). Secara simultan anak mengembangkan model yang paralel dalam dirinya. Anak dengan orang tua yang mencintai akan memandang dirinya "berharga". Model ini selanjutnya akan digeneralisasikan anak dari orang tua pada orang lain, misalnya pada guru dan teman sebaya. Anak akan berpendapat bahwa guru dan teman adalah orang yang dapat dipercaya. Sebaliknya, anak yang memiliki pengasuh yang tidak menyenangkan akan mengembangkan kecurigaan (mistrust) dan tumbuh sebagai anak yang pencemas dan kurang mampu menjalin hubungan sosial.

Adapun informan An hanya sedikit mendapat perhatian dari orang tuanya. Ibu menerapkan pola asuh yang otoriter yang sering marah-marah, egois, dan sering bertengkar dengan ayah tirinya. Akibatnya, An sedikit mengembangkan perilaku yang menurutnya ia nakal. Namun, ayah kandung informan masih cukup perhatian karena masih sering berkomunikasi dan pernah mengajak An menginap ke tempat tinggal bersama istri yang baru .

Keluarga merupakan lembaga pertama dalam kehidupan anak, tempat belajar sebagai makhluk sosial juga merupakan dasar pembentukan tingkah laku, watak, moral dan pendidikan anak. Interaksi di dalam keluarga akan menentukan pula tingkah laku terhadap orang lain dalam masyarakat. Orang tua sangat besar peranan dan tanggung jawabnya dalam mendidik dan membimbing anak-anaknya. Intensitas kehadiran orang tua untuk bertemu anaknya mempengaruhi pembentukan kepribadian.

Frued (Hurlok, 2008) mengemukakan perkembangan seseorang sangat ditentukan oleh pengalaman awal masa kanak-kanaknya yang tingkat kepuasan masa kanak-kanak akan sangat mempengaruhi tingkah laku seseorang di kemudian hari. Pada tahap awal perkembangan individu menurut Freud peran yang menonjol di dalam kehidupan seorang anak adalah ibu. Hal ini berkaitan dengan perbedaan struktur biologis antara ibu dan ayah. Sejak bayi lahir, ibulah yang menyusui serta menyuapi makanan ke mulut bayi yang hubungan ini sangat berpengaruh di dalam pembentukan kepribadian dan sikap-sikap sosial anak di kemudian hari. Di mata Freud, peran ayah tidak diperhitungkan. Peran ayah 
baru muncul pada tahap terakhir masa kanak-kanak. Dagun (2004) menambahkan dalam kelompok anak yang ditinggalkan ayahnya sebelum usia lima tahun kelihatan bahwa kemampuan akademiknya menurun bila dibandingkan dengan anak yang ayahnya terlibat penuh dalam proses pembinaan perkembangan anak. Namun demikian, meskipun ayah hidup bersama dengan anak, kalau kurang terlibat dalam pembinaan, maka kehadirannya hampir tidak ada dampaknya, bahkan nasib anaknya boleh dikatakan sama dengan anak yang ditinggalkan ayahnya. Yang dimaksud ditinggalkan ayahnya disini ialah bisa karena perceraian, meninggal, atau juga tidak terlibat dalam proses pembinaan secara langsung perkembangan anak. Kondisi ini juga dialami oleh semua informan bahwa dari segi akademis (kognitif) tidak ada yang memperoleh prestasi akademis tinggi di kelas.

\section{c. Jenis kelamin}

Berdasarkan hasil interpretasi wawancara dan observasi informan perempuan cenderung lebih mampu mengelola emosinya dengan baik, dan saat menghadapi masalah terbiasa bercerita kepada orang-orang terdekatnya. Seperti pada informan Vn dan An yang sering bercerita dengan Bude dan kakek-neneknya. Adapun informan laki-laki (Dn) cenderung menutup diri, bahkan tidak ingin tahu apa penyebab kedua orang tuanya berpisah. Saat proses wawancara informan Dn juga tidak banyak bercerita.

Mendukung hasil di atas Kartono (2000) mengungkapkan laki-laki dan perempuan berbeda bila dilihat dari ciri-ciri jasmaniah. Perbedaan secara anatomis dan fisiologis ini menyebabkan pula perbedaan pada tingkah laku laki-laki dan perempuan. Perbedaan ini diperkuat oleh struktur kebudayaan yang ada sejak dahulu. Walaupun struktur-struktur didunia dan norma-norma tradisional telah berubah namun keberadaan dan sifat antara kedua jenis laki-laki dan perempuan tetap berbeda. Perempuan akan lebih dekat dengan masalah-masalah kehidupan praktis, kongkrit, lebih spontan, bergairah, penuh vitalitas hidup, heterosentris, dan sosial. Adapun pria lebih egosentris dan tertarik pada segi kejiwaan yang bersifat abstrak. Gunarsa (2005) menambahkan bahwa ada pembatasan pikiran, rasio, dan emosionalitas. Jalan pikiran pria tidak dikuasai emosi, perasaan maupun suasana hati.

Menurut hasil penelitian Wirawan (2010) pemaknaan kebahagiaan dari segi spiritual lebih dapat dimaknai oleh informan perempuan sebab perempuan lebih bersifat afektif dalam melakukan serta memaknai segala hal dibandingkan dengan laki-laki yang lebih menggunakan logika dalam menanggapi masalah yang ada. Selain itu, perempuan dalam bertindak juga lebih banyak memanfaatkan afeksi dibandingkan logikanya sehingga kebahagiaan lebih dimaknai sebagai hal yang bersifat spiritual, yang terkait dengan relasinya dengan Tuhan. Laki-laki dalam penelitian lebih memaknai kebahagiaan dari segi personal konkret, dan tidak banyak laki-laki yang dapat memaknai kebahagiaan dari segi eksistensial dan spiritual. Ada kemungkinan hal ini disebabkan mereka lebih menggunakan logikanya dibandingkan dengan perasaannya sehingga pemaknaannyapun lebih cenderung ke arah dirinya sendiri (personal). Namun, semakin dewasa dan semakin matang usia laki-laki, individu akan semakin dapat memaknai kebahagiaan dari segi spiritual. Hal ini disebabkan individu semakin menyadari hubungannya dengan Tuhan serta semakin matang dalam berpikir sehingga lebih mampu menelaah arti dari suatu kejadian dari segala sisi, termasuk dari sisi spiritual. Baik partisipan laki-laki maupun perempuan juga dapat memaknai kebahagiaan dari sisi eksistensial. Baik laki-laki maupun perempuan dapat mensyukuri setiap hal yang dimilikinya serta dapat melihat masalah dari sisi positif dari setiap peristiwa yang terjadi walaupun peristiwa tersebut tidak menguntungkan. Hal ini terjadi karena informan dari penelitian ini berusia dewasa, sehingga telah lebih matang 
dalam berpikir serta telah mampu mengelola emosi sehingga lebih dapat memetik makna dari setiap kejadian yang ada.

\section{d. Faktor ekonomi}

Faktor ekonomi juga berperan besar dalam pembentukan subjective well being. Pada informan $\mathrm{Vn}$ dan $\mathrm{An}$, dengan kondisi ekonomi yang serba kekurangan menyebabkan beban pikiran informan bertambah berat, informan terkadang pesimis apakah bisa melanjutkan ke SMA atau tidak, bahkan sebab pertengkaran Pakde Bude adalah karena faktor ekonomi.

Berkaitan dengan hal tersebut Gerungan (2006) menyatakan bahwa keluarga yang berada dalam status sosial ekonomi serba kecukupan, maka orang tua mencurahkan perhatiannya lebih mendalam kepada kebutuhan anak-anaknya terutama dalam bidang pendidikan. Mereka tidak dipersulit perkara kebutuhan primer manusia walaupun demikian, ia juga menambahkan bahwa status sosial ekonomi keluarga bukan merupakan faktor mutlak yang mempengaruhi perkembangan anak, namun status sosial ekonomi keluarga tetap dikatakan sebagai suatu faktor yang penting.

Sebagian masyarakat petani di desa umumnya mempunyai pendidikan yang kurang, orang tua yang hanya lulus SD, dan yang tidak lulus SD. Salah satu sifat petani adalah orientasi pada harta benda. Mereka mendapatkan hasil yang sangat kecil serta untuk memenuhi kebutuhan yang bersifat fisik dan kurang memperhatikan kebutuhan anakanaknya. Hal ini mempengaruhi pemahaman dan pengetahuan akan manfaat dan pentingnya pendidikan bagi anak. Salah satunya berpengaruh terhadap keadaan anak-anak yang tidak melanjutkan sekolah setelah mereka lulus, khususnya menuju jenjang pendidikan yang lebih tinggi. Mutrofin (2009) mengatakan sebagian dari masyarakat, terutama di daerah pedesaan masih cukup banyak yang beranggapan bahwa bersekolah hanya untuk memperoleh ijazah. Sekolah tidak dipandang sebagai lembaga yang dapat memberi bekal bagi anak-anak guna mengembangkan dirinya. Beranjak dari pandangan demikian, orang tua dari anak sekolah cenderung mengarahkan anaknya untuk menyelesaikan sekolah hingga mencapai pendidikan dasar saja. Lebih memprihatinkan lagi perlakuan terhadap anak-anak perempuan yang cenderung diabaikan, tidak hanya dari segi kesempatan untuk bersekolah, tetapi juga tidak mendapat dukungan. Kesadaran anak-anak usia sekolah pada daerah-daerah tertentu cenderung diarahkan pada kesulitan hidup, tuntutan ekonomi, serta sikap pesimis menghadapi persaingan kerja. Kondisi ini secara signifikan menurunkan minat dan motivasi anak-anak untuk bersekolah.

\section{e. Strategi coping}

Berdasarkan hasil wawancara diketahui bahwa semua informan pada awalnya merasa kecewa, sedih, tertekan, dan menangis. Informan mengekspresikan hal tersebut dalam mekanisme coping yang berbeda-beda. Informan Vn dan An cenderung melakukan coping yang berorientasi pada problem, yaitu berusaha menghadapi penyebab timbulnya masalah secara langsung. Usaha yang dilakukan oleh individu lebih diarahkan kepada bentuk-bentuk tingkah laku yang ditujukan untuk menyelesaikan masalah tersebut. Vn lebih memilih meningkatkan aktivitas beribadah dan mengerjakan pekerjaan rumah untuk sekadar mengurangi atau melupakan masalah yang dihadapi. Sementara itu, An cenderung melupakan masalah tersebut dengan berkumpul dengan teman-teman dan mengalihkan dalam kegiatan olahraga lompat jauh (juara 1 popda). Adapun Dn strategi coping cenderung berorientasi pada emosi, yaitu mengurangi atau menghilangkan permasalahan dengan cara mengatur tekanan-tekanan emosi yang dirasakan dan untuk mempertahankan keseimbangan afeksinya, diantaranya tidak mau tahu penyebab perceraian orang tuanya, 
menjaga perasaan ibunya, dan merasa bahwa sekarang ia sudah hidup dapat dengan ibunya.

\section{f. Religiusitas}

Agama mendorong pemeluknya untuk berperilaku baik dan bertanggung jawab atas perbuatannya. Selain itu, agama mendorong pemeluknya untuk berlomba-lomba dalam kebaikan. Seperti dikemukakan oleh Jalalludin (2002:75) bahwa tingkat religiusitas pada diri remaja akan berpengaruh terhadap perilakunya. Jadi, remaja yang memiliki tingkat religiusitas tinggi, mereka akan menunjukkan perilaku ke arah hidup yang religius, sebaliknya remaja yang memiliki tingkat religiusitas rendah, mereka akan menunjukkan perilaku ke arah hidup yang jauh dari religius pula.

Agama juga mengajarkan kepada pemeluknya untuk mensyukuri segala hal yang terjadi dalam kehidupannya, serta tawakal dalam menerima cobaan dari Allah karena Alloh telah merencanakan jalan hidup setiap orang. Informan Vn sejak kecil telah diajarkan nilainilai agama oleh Pakde-Budenya. Bahkan Pakde Budenya juga memberikan contoh dalam bentuk perilaku yaitu rajin salat lima waktu. Selain itu, Pakde Bude Vn juga seringkali mengingatkan Vn agar tidak meninggalkan sholat, sehingga ketika Vn mengalami masalah maka Vn kemudian salat dan berdoa. Hal ini membuat Vn lebih tenang, nyaman, dan kuat. Informan Dn sejak kecil juga diajarkan oleh ibunya untuk menjalankan sholah lima waktu, namun Dn belum dapat penuh menjalankan penuh ibadah sholat lima waktu, sedangkan pada informan An sejak orang tuanya kurang memperhatikan masalah agama, sehingga An juga kurang terbiasa dengan ibadah lima waktu. Hal ini membuat An kurang dekat dengan Alloh sehingga ketika mengalami masalah An tidak melakukan pendekatan melalui agama.

\section{Kondisi SWB pada informan}

Ada beberapa kejadian atau peristiwa yang memberikan kepuasan hidup pada informan VN, diantaranya yaitu ketika ia lulus SD dengan nilai yang cukup baik, menerima kasih sayang dari Pakde-Bude, teman-teman dapat memahami kondisi keluarga subjek sehingga mereka dapat menerima VN dalam pergaulan. Informan Vn sejak kecil diasuh oleh PakdeBude-nya, selama pengasuhan tersebut Pakde-Bude selalu mencukupi semua kebutuhan baik secara materi maupun kasih sayang. Pakde Bude mengajarkan untuk tidak membenci orang tua, mengajarkan untuk salat, berdoa dan belajar. Pengaruh dari pola pengasuhan yang positif tersebut perkembangan perilaku sosial Vn cukup baik karena memiliki sifat yang terbuka, mau berbagi dan bercerita dengan orang terdekat mengenai masalahnya. Selain itu Vn menggunakan strategi coping dengan cara salat, dan berdoa juga dengan bersih-bersih rumah, seperti menyapu dan mencuci piring. Vn menganggap Pakde-Bude seperti orang tua kandungnya sendiri. Kegiatan positif lain yang dilakukan Vn yaitu membantu Pakde jualan mie ayam. Kondisi psikologis Vn cukup baik karena ia memiliki semangat yang tak pernah padam dalam menghadapi berbagai masalah sehari-hari. Selain itu, Vn memiliki kepribadianyang cukup matang karena sudah mampu menyadari bahwa perceraian orang tuanya sudah takdir sehingga ia tidak menyesali terus-menerus. Pada Vn terdapat beberapa afek negatif, diantarnya yaitu sedih dan merasa menjadi beban karena Pakde-Bude sering bertengkar masalah keuangan. Vn juga kecewa karena kedua orang tua kandung tidak pernah lagi mengirimi uang. Merasa sudah tidak dipedulikan orang tua karena ibu kandung juga sudah 2 tahun tidak pulang, tidak ada saudara yang menengok. Vn merasa kesal dengan keadaan dan terkadang berprasangka negatif pada para tetangga yang dianggap tidak bersimpati dengan keadaan keluarganya tetapi justru seolah-olah memandang sinis kondisi keluarganya. 
Kepuasan hidup Dn dirasakan karena ia masih mendapatkan perhatian dan kasih sayang dari kedua orang tuanya. Ayahnya masih sering menelpon. Selain itu, Dn juga merasa damai dan nyaman karena bisa tinggal bersama ibu di rumah sendiri, meskipun ibu bekerja namun masih memperhatikan baik dalam kegiatan belajar maupun kegiatan bermain. Dn merasa hidupnya berjalan seperti dengan baik, tidak merasa mempunyai masalah. Subjek merasa senang karena mendapat hadiah sepeda ketika ia lulus SD. Informan Dn, selain tetap dekat dengan kedua orang tunya, ia juga dekat dengan kakek neneknya dan merasa senang karena sering diajak berlibur atau jalan-jalan oleh kakek nenek. Faktor afek positif yang lain yaitu subjek merasa senang karena teman-teman dan tetangganya bersikap pada baik padanya sehingga ia dapat bergaul dengan baik. Dalam kegiatan belajar informan tetap bersemangat sekolah, ia berusaha mendapatkan nilai yang tinggi karena jika nilai pelajaran memuaskan ia merasa senang dan bangga. Meskipun orang tua sudah bercerai, Dn merasa selama ini hidupnya tidak ada masalah, ia merasa sesuatu berjalan dengan baik. Informan Dn merasa sedih dan kasihan melihat ibunya mencari nafkah sendiri dan ia juga sering merasa sedih jika memikirkan ayahnya. Semenjak perceraian orang tuanya Dn mengaku menjadi pendiam. Oleh karena itu, Dn sangat berharap kedua orang tuanya dapat bersatu kembali. Sesuatu yang membuatnya takut dan merasa bersalah adalah ketika ia dimarahi ibunya karena terlalu lama bermain, dan selebihnya tidak ada hal-hal atau faktor yang membuatnya merasa sedih atau kecewa.

Informan An mendapat kepuasan dalam kehidupan terutama yaitu ketika menjuarai lomba lompat jauh tingkat Kabupaten Wonogiri. Keberhasilan tersebut membuat kebanggaan pada diri informan sehingga meningkatkan keyakinan dan optimis pada informan untuk mencapai prestasi yang lebih tinggi lagi. Kepuasan hidup lainnya yang dirasakan yaitu dapat bertemu dengan ayah kandungnya. Pertemuan dengan ayah kandung tersebut membuat informan merasa senang dan lega. Informan memiliki banyak teman dan tetangga yang baik yang siap membantu ketika informan mengalami masalah. Adanya dukungan ini membuat informan kuat dan lebih tegar menghadapi cobaan hidup yang dialami. Kumpul bersama teman-teman juga membuat informan merasa senang, lebih bersemangat dan percaya diri dalam bergaul. Informan merasa optimis mampu menjadi atlet nasional. Hal ini sudah menjadi harapan atau keinginan informan selama ini sehingga informan berusaha berlatih keras untuk mencapai keinginan tersebut. Selama ini informan sering merasakan emosi negatif dalam hidupnya. Merasa hidup berat, batinnya tertekan karena melihat sikap ibu yang egois, berwatak keras dan sering marahmarah. Informan mengakui bahwa selama ini ia tidak merasa bahagia, selain karena perceraian ditambah lagi sikap ibu yang egois, dan sering bertengkar dengan ayah tirinya. Persoalan lain yang membuat informan semakin tertekan yaitu kakek-neneknya ternyata juga bercerai. Kondisi keuangan sehari-hari juga serba kurang, hal ini semakin menyebabkan informan semakin tertekan dan merasa sedih. Di samping itu, informan merasa iri melihat teman-temanya yang memiliki keluarga utuh dan harmonis, subjek sering membanding-bandingkan dirinya dengan orang lain.

Dalam tinjauan secara umum Penelitian Thomas dan Diener (Diener, Lucas \& Oshi, 2005) menemukan bahwa kebahagiaan dipengaruhi oleh suasana hati individu pada suatu saat tertentu, keyakinannya tentang kebahagiaan, serta seberapa mudahnya seseorang menerima informasi positif dan negatif. Di sisi lain, sejumlah pakar juga mengaitkan kebahagiaan dengan seberapa mampu individu mempersepsi pengalaman hidupnya secara positif. Tingkat kebahagiaan akan berubah seiring berjalannya perjalanan hidup seseorang, terutama karena kejadian-kejadian di hidup yang dapat meningkatkan kebahagiaan (pernikahan, kelahiran anak, kesuksesan, dll.). Namun kebahagiaan juga dapat menurun karena adanya peristiwa yang menyedihkan (kematian kerabat, perceraian, dan kegagalan) sehingga tingkat kebahagiaan tidak akan 
menetap. Perubahan tingkat kebahagiaan seseorang disebabkan adanya kemampuan adaptasi individu terhadap situasi di lingkungannya.

Pada dasaranya seseorang akan lebih berbahagia ketika mendapatkan pengalaman yang menyenangkan. Begitu juga sebaliknya, ketika seseorang kecewa dengan pengalamannya, seperti liburan yang ternyata mengecewakan, ataupun usaha yang kemudian gagal, hal ini akan membuat kebahagiaan menurun. King (Wirawan, 2010) mengemukakan pengalaman yang buruk akan lebih cepat menurunkan tingkat kebahagiaan dibandingkan dengan kegagalan dalam memilih barang yang bersifat hanya material. Namun, kemampuan seseorang untuk melakukan introspeksi dan mengambil hikmah dari berbagai peristiwa yang terjadi ternyata berperanan juga terhadap kebahagiaannya. Laura King, peneliti dari University of Missouri, mengindikasikan bahwa individu yang menghabiskan waktu untuk memikirkan kesalahan yang telah mereka lakukan (instropeksi diri) cenderung menjadi lebih dewasa dan dapat menambah potensi kebahagiaan mereka. King menemukan bahwa orang-orang yang dapat menunjukkan perkembangan kepribadian adalah orang-orang yang pernah merasakan kehilangan.

Kebahagiaan adalah salah satu konsep penting dalam psikologi positif dan menjadi salah satu indikator dalam kesejahteraan subjektif (subjective well-being). Ada berbagai pemaknaan tentang kebahagiaan: sebagian mempersepsinya sebagai tujuan akhir dari kehidupan seseorang, sebagian melihatnya sebagai bagian dari perjalanan hidup itu sendiri, sebagai buah dari perbuatan seseorang. Penelitian Lyubomirsky (Wirawan, 2010) dari University of California yang dipublikasikan oleh American Psychological Association (APA) menemukan bahwa orang-orang yang berbahagia akan lebih berhasil di sepanjang rentang hidupnya dibandingkan dengan orang yang kurang berbahagia. Di samping itu, orang yang berbahagia akan lebih mudah mencapai situasi kondisi kehidupan yang lebih menyenangkan. Hal ini dimungkinkan terjadi karena orang yang berbahagia kerap kali mengalami suasana hati yang positif dan suasana hati positif ini menggugah mereka untuk bekerja dengan lebih aktif untuk mencapai tujuan yang baru dan membangun sumber daya yang baru. Ketika orang merasa berbahagia, mereka cenderung merasa percaya diri, optimis, dan energik, dan orang lain berpandangan bahwa mereka adalah orang-orang yang lebih disukai dan lebih mudah bergaul.

Nakonezny, Shull, dan Rodgers, (1995) menyimpulkan bahwa konflik rumah tangga menghentikan proses kelekatan pada anak-anak dan menyebabkan rasa tidak aman secara emosional yang pada gilirannya membuat anak-anak menjadi lebih mudah terbangkitkan emosi negatif dan merasa tertekan, dan lebih sulit untuk dapat mengendalikan emosinya serta kurang dapat berpikir optimis mengenai kemampuan mereka mengatasi episode konflik perkawinan selanjutnya. Selanjutnya, Cummings, Simpson, dan Wilson, (2003) dalam penelitiannya mengenai hubungan antara konflik pernikahan dan penyesuaian anak, mengembangkan design penelitian di mana konflik dalam perkawinan yang terjadi pada orang tua akan mempengaruhi respon anak dalam mengatasi konflik, proses serta gaya anak dalam menghadapi konflik perkawinan yang pada gilirannya akan berpengaruh terhadap perkembangan anak.

Remaja membutuhkan pengertian dan bantuan dari orang yang dicintai dan dekat dengannya terutama orang tua atau keluarganya. Fungsi keluarga adalah memberi pengayoman sehingga menjamin rasa aman maka dalam masa kritisnya remaja sungguh-sungguh membutuhkan realisasi fungsi tersebut. Hal ini disebabkan karena dalam masa yang kritis seseorang kehilangan pegangan yang memadai dan pedoman hidupnya. Masa kritis diwarnai oleh konflik-konflik internal, pemikiran kritis, perasaan mudah tersinggung, dan cita-cita dan kemauan yang tinggi, tetapi sukar dikerjakan sehingga seseorang menjadi frustasi dan sebaginya. Masalah keluarga yang broken home bukan menjadi masalah baru tetapi merupakan masalah yang utama dari akar-akar kehidupan seorang anak. Keluarga merupakan dunia keakraban dan diikat oleh tali batin sehingga menjadi bagian yang vital dari kehidupannya (Hurlock, 2008). 
Secara umum informan penelitian memiliki tingkat kebahagiaan yang relatif baik, namun demikian hal tersebut tidak menetap, dalam arti bisa naik dan bisa menurun. Hal ini dapat dipengaruhi oleh peristiwa atau kejadian-kejadian yang dialami oleh informan, terlebih usia informan yang masih remaja awal. Sesuai dengan Penelitian Thomas dan Diener (Diener, Lucas, dan Oshi, 2005) menemukan bahwa kebahagiaan dipengaruhi oleh suasana hati individu pada suatu saat tertentu, keyakinannya tentang kebahagiaan, serta seberapa mudahnya seseorang menerima informasi positif dan negatif. Di sisi lain, kebahagiaan juga berkaitan dengan seberapa mampu individu mempersepsi pengalaman hidupnya secara positif. Tingkat kebahagiaan akan berubah seiring berjalannya perjalanan hidup seseorang, terutama karena kejadian-kejadian hidup yang dapat meningkatkan kebahagiaan (pernikahan, kelahiran anak, kesuksesan, dll.), namun kebahagiaan juga dapat menurun karena adanya peristiwa yang menyedihkan (kematian kerabat, perceraian, dan kegagalan), sehingga tingkat kebahagiaan tidak akan menetap. Perubahan tingkat kebahagiaan seseorang disebabkan adanya kemampuan adaptasi individu terhadap situasi di lingkungannya. Ditambahkan oleh King (Wirawan, 2010) pengalaman yang buruk akan lebih cepat menurunkan tingkat kebahagiaan dibandingkan dengan kegagalan dalam memilih barang yang bersifat hanya material. Seseorang akan lebih berbahagia ketika mendapatkan pengalaman yang menyenangkan. Begitu juga sebaliknya, ketika seseorang kecewa dengan pengalamannya, seperti liburan yang ternyata mengecewakan, ataupun usaha yang kemudian gagal, hal ini akan membuat kebahagiaan menurun.

Pada informan VN dan Dn SWB cenderung tinggi. Hal ini dikarenakan informan Vn dan Dn mendapatkan pola asuh yang baik dari orang tua. Walaupun orang tua Vn sebenarnya bukan orang tua kandung, tetapi karena perlakuan Pakde Bude terhadap Vn seperti perlakuan orang tua terhadap anaknya sendiri dan Pakde Bude mengajarkan agama yang baik. Informan Dn walaupun tinggal dengan ibu saja, tetapi ibu Dn mengajarkan hal-hal yang baik, memberikan kasih sayang, tetap memperhatikan masalah belajar anaknya, dan tidak melibatkan anak terhadap masalah kedua orang tuanya. Adapun informan An SWB-nya cenderung rendah karena pola asuh yang kurang baik dari orang tua. Sejak kecil An sudah terbiasa dengan konflik antara kedua oran tuanya, bahkan An sering disalahkan ketika kedua orangtunya sedang bertengkar. Ekonomi yang kekurang juga membuat ibu An sering marah-marah kepada An, hal ini menyebabkan An sering merasa jengkel dan marah-marah. Selain itu orang tua An kurang mengajarkan agama kepada anaknya. Hal ini membuat An seperti kehilangan pegangan ketika menghadapi masalah. Tidak ada tuntunan dan panutan dalam keluarga An sehingga An kesulitan mendapatkan contoh sikap yang tepat dalam menghadapi masalah.

Kebaruan hasil penelitian mengenai subjective well-being bahwa hasil penelitian ini menunjukkan bahwa faktor-faktor yang mempengaruhi subjective well-being adalah dukungan sosial, pola asuh orang tua, jenis kelamin, ekonomi, strategi coping, dan religiusitas. Hasil penelitian Diener dkk. (2005) mengindikasikan bahwa terdapat beberapa faktor yang mempengaruhi subjective well-being yaitu : kepribadian, emosi, kesehatan fisik, budaya, kelas sosial dan kekayaan, kelekatan dan relasi intim, dan pencapai tujuan. Terdapat perbedaan faktor-faktor yang mempengaruhi subjective well-being antara hasil penelitian ini dengan hasil penelitian Diener dkk.(2005).

\section{SIMPULAN}

Faktor faktor subjective well-being pada masing-masing informan dideskripsikan sebagai berikut. (a) Informan Vn; 1) faktor pendukung yang berpengaruh diantaranya dukungan sosial dan pola asuh yang baik dari Pakde-Bude, memiliki sifat terbuka, berdoa dan rajin bersih-bersih. 2) faktor resiko yang berpengaruh diantaranya, melihat Pakde-Bude sering bertengkar masalah ekonomi, terpancing sering bicara kasar, tertekan, dan kesulitan keuangan. (b) Informan Dn; 1) 
faktor pendukung yang berpengaruh diantaranya tetap mendapat dukungan sosial dari orang tua kandung, dapat menjaga perasaan ibu dengan tidak menanyakan penyebab perceraian; sering diam dan bermain dengan teman-teman dan 2) faktor resiko yang berpengaruh diantaranya, sering memikirkan orang tua, dan memikirkan nilai belajar yang jelek. (c) Informan An; 1) faktor pendukung, mendapat dukungan dari teman dan tetangga, bersikap terbuka dengan orang-orang terdekat, dapat berkumpul bersama teman-teman dan 2) faktor resiko yang berpengaruh diantaranya, sering melihat ibu marah, tidak bersemangat, dan sering berkhayal.

Kondisi subjective well-being informan VN dan Dn SWB cenderung tinggi, hal ini dikarenakan informan Vn dan Dn mendapatkan pola asuh yang baik dari orang tua. Walaupun orang tua Vn sebenarnya bukan orang tua kandung, perlakuan Pakde Bude terhadap Vn seperti perlakuan orang tua terhadap anaknya sendiri dan Pakde Bude mengajarkan agama yang baik. Informan Dn walaupun tinggal dengan ibu saja, tetapi ibu Dn mengajarkan hal-hal yang baik, memberikan kasih sayang, tetap memperhatikan masalah belajar anaknya, dan tidak melibatkan anak terhadap masalah kedua orang tuanya. Adapun informan An SWB-nya cenderung rendah karena pola asuh yang kurang baik dari orang tua. Sejak kecil An sudah terbiasa dengan konflik antara kedua orantuanya, bahkan An sering disalahkan ketika kedua orangtunya sedang bertengkar. Ekonomi yang kekurang juga membuat ibu An sering marah-marah kepada An, hal ini menyebabkan An sering merasa jengkel dan marah-marah. Selain itu orang tua An kurang mengajarkan agama kepada anaknya. Hal ini membuat An seperti kehilangan pegangan ketika menghadapi masalah. Tidak ada tuntunan dan panutan dalam keluarga An sehingga An kesulitan mendapatkan contoh sikap yang tepat dalam menghadapi masalah.

\section{DAFTAR PUSTAKA}

Cummings, E. M., Simpson, K S., \& Wilson, A. (2003). Children's Responses to Interadult Anger as a Function of Information about Resolution. Journal of Developmental Psychology. 93, Vol. 29, No. 6, 978-985.

Dagun, S. M. (2004). Psikologi Keluarga. Jakarta : PT. Asdi Mahasatya.

Diener, E., Lucas, R.E. \& Oshi S. (2005). Subjective Well-Being: The Science and Happiness and Life Satisfaction. Handbook of Positif Psychology. Oxford; Oxford University Press.

Gerungan, W. W. (2006). Psikologi Sosial. Bandung: PT Refika Aditama

Hurlock, E. B. (2008). Psikologi Perkembangan: Suatu Pendekatan Sepanjang Rentang Kehidupan (Terjemahan oleh Istiwidayati Tjandrasa). Jakarta: Erlangga.

Kartono, K. (2010). Psikologi Wanita jilid 2: Mengenal Wanita sebagai Ibu dan Nenek. Bandung: Mandar Maju

Maramis W.F. (2000). Catatan Ilmu Kedokteran Jiwa. Surabaya: Airlangga University Press.

Marlina, E. (2008). "Peran Konsep Diri dan Dukungan Sosial terhadap Kecemasan Berbicara di Muka Umum Mahasiswa Fakultas Dakwah”. Tesis (tidak dipublikasikan). Yogyakarta: Fakultas Psikologi Universitas Gajah Mada

Mc. Cartney, K. \& Dearing, E., (Ed). (2002). Child Development. Mc.Milan Refference USA

Mutrofin. (2009). Mengapa Mereka Tidak Bersekolah, Evaluasi Program Kewajiban Belajar. Jakarta: Kaksbang Pressindo.

Nakonezny, P.A., Shull, R.D., Rodgers, J.L. (1995). The Effect of No-Fault Divorce Law on the Divorce rate Across The 50 States and its Relation to Income, Education, and Religiosity. 
Journal of Marriage and The Family, 57, 477-488

Rachmat, Jalaludin. (2002). Psikologi Komunikasi edisi Revisi. Bandung: PT. Remaja Rosdakarya.

Seligman, M E.P. (2006). Autenthic Happiness. Bandung: Mizan Media Utama

Taufik.(2010). Psikologi untuk Kebidanan dari Teori ke Praktek. Surakarta: Eastview.

Watson, D., \& Clark, L.A. Tellegen, A., (1988). "Development and Validation of Brief Measurres of Positive a Negative affect: The PANAS Scale". Journal of Personality and Social Psychology. 54 (5), 1063-1070

Wirawan, H.E. (2010) “Kebahagiaan menurut Dewasa Muda Indonesia”. Laporan Penelitian. Jakarta: Universitas Tarumanagara. 